\title{
Enhanced radiosensitivity of SW480 cells via TRAIL up-regulation mediated by Egr-1 promoter
}

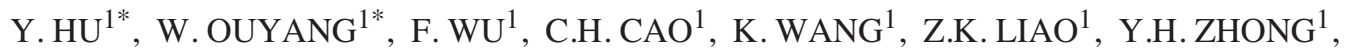

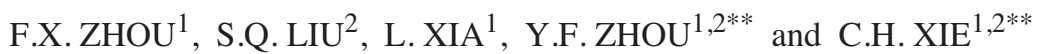 \\ ${ }^{1}$ Department of Radiation and Medical Oncology, ${ }^{2}$ Hubei Key Laboratory of Tumor Biological Behaviors, \\ Zhongnan Hospital, Wuhan University, 169 Donghu Road, Wuchang District, Wuhan, 430071, P.R. China
}

Received May 26, 2009; Accepted July 6, 2009

DOI: $10.3892 /$ or_00000498

\begin{abstract}
Radiosensitization of cancer cells to irradiation could improve the efficacy of radiotherapy. The early transcriptional factor (Egr-1) promoter induced expression of downstream genes after irradiation. TNF-related apoptosisinducing ligand (TRAIL) is known to induce apoptosis in malignant cells, but displayed little or no toxicity on normal cells. In this study, we constructed pcDNA3.1-Egr-1-TRAIL (pEgr.1-TRAIL) recombinant plasmid and evaluated its effect on human colon cancer cell line SW480. pEgr.1-TRAIL transfection combined with radiotherapy caused dramatically elevation of TRAIL expression both in mRNA and protein levels, much lower radiobiological parameters in clonogenic assays, accompanied by remarkably increase in apoptosis ratio. Furthermore, pEgr.1-TRAIL transfected cells displayed higher proportion in G0/G1 phase. Our results suggested that pEgr.1-TRAIL can sensitize SW480 cells to radiation, and the radiosensitization is related to cell cycle changes and apoptosis mediated by up-regulation of TRAIL expression. These findings support the potential future application of genetic radiotherapy against carcinoma.
\end{abstract}

\section{Introduction}

Radiotherapy is a widely used local and regional modality for the treatment of cancer. New developments in radiotherapy technologies, such as 3-D conformal radiotherapy, intensity modulation radiated therapy, make radiotherapy more acceptable. However, one of the main disadvantages

Correspondence to: Dr Cong-Hua Xie, Department of Radiation and Medical Oncology, Zhongnan Hospital, Wuhan University, 169 Donghu Road, Wuchang District, Wuhan, 430071, P.R. China E-mail: chxie_65@hotmail.com

${ }^{*}$ Contributed equally

** Joint senior authorship

Key words: Egr-1 promoter, TRAIL, SW480 cells, apoptosis, radiosensitivity is their complete reliance on dose-escalation, which make it impossible to achieve sufficient dose to eradicate radioresistant tumors without unacceptable acute and late normal tissue toxicity (1). Radiotherapy remains facing difficulties like recurrence or metastasis after radiation and damage to normal tissues surrounding the tumor $(2,3)$.

Cancer gene therapy (CGT) is a novel treatment of great interest. However, CGT has failed to fulfill its initial promise of improving overall treatment outcome due to tumorigenesis is a multi-step process (4). There is increasing acceptance of the fact that CGT is unlikely to succeed as a single modality (1). However, combining with radiotherapy to improve the overall response rate and the therapeutic index seems to be feasible. In addition, there have been studies showing that radiation improves the efficiency of gene transference $(5,6)$. Combination of radiotherapy with gene therapy potentially provides new modes of targeting toxicity on malignant cells, with minimal effect on normal cells (7).

Egr-1 gene is a member of the immediate early gene family, and its promoter can be rapidly induced by various stimuli like irradiation, mitogens and growth factor (8). The selection of downstream gene is crucial to the efficacy of gene therapy. Tumor necrosis factor-related apoptosis-inducing ligand (TRAIL) belongs to the TNF super family, which plays important roles in regulating cell death, immune response and inflammation $(9,10)$. The specificity of TRAIL, compared with other members of the TNF family, is its ability to induce apoptosis in a variety of malignant cells, while displaying minimal toxicity on normal cells and tissues (11). Moreover, combine TRAIL gene therapy with radiotherapy has been reported to induce a synergistic effect on apoptosis in cancer cells (12), which may be attributed to the up-regulation of TRAIL receptors by radiation $(12,13)$. To study the feasibility of radiation inducible gene therapy, we constructed a combined plasmid containing the Egr-1 promoter and cDNA of the gene encoding TRAIL (pcDNA3.1-Egr-1-TRAIL), and investigated whether this genetic radiotherapy could enhance the radiosensitivity in SW480 cells.

\section{Materials and methods}

Plasmid construction. Dr Wu Cong-Mei (Medical College of Shantou University, Guangdong, China) kindly provided the 
plasmid pMD18T-Egr-1 and Dr J.Y. Chang (The University of Texas M.D. Anderson Cancer Center, TX, USA) gave the plasmid PAAV-TRAIL. pcDNA3.1+ vector was purchased from Invitrogen Life Technologies. The Method of TRAIL expression vector construction was described in our previous study (14).

Cell lines and culture conditions. The human colon cancer cell line SW480 was obtained from the China Center for Type Culture Collection (CCTCC) in Wuhan University. Cells were cultured in RPMI-1640 medium (Hyclone) at $37^{\circ} \mathrm{C}$ in a humidified atmosphere of $5 \% \mathrm{CO}_{2}$. The media were supplemented with $10 \%$ heat-inactivated fetal bovine serum and $1 \%$ penicillin/streptomycin and was changed every 3-5 days.

Grouping and irradiation. The cells were divided into 4 groups: i) control group (no treatment was performed); ii) gene radiotherapy group (treated with transfection of pcDNA 3.1-pEgr-1-TRAIL and irradiation); iii) gene therapy group (treated with transfection of pcDNA3.1-pEgr-1-TRAIL only); and iv) radiotherapy group (treated with irradiation only). Monolayer of cells in gene radiotherapy group and radiotherapy group were irradiated for $6 \mathrm{~Gy}\left({ }^{60} \mathrm{Co} \gamma\right.$-ray machine, field $=20 \mathrm{~cm}$ x $20 \mathrm{~cm}, \mathrm{SSD}=80 \mathrm{~cm}$, dose rate $\left.=96 \mathrm{cGy} \mathrm{min}^{-1}\right)$. The cells were cultured for $24 \mathrm{~h}$ after irradiation.

Transfection. A total of $5 \times 10^{5} \mathrm{SW} 480$ cells were plated into each well of 6-well plates. When the cells achieved 80-90\% confluency, the culture medium was removed. Cells in gene radiotherapy group and gene therapy group were transfected in an appropriate ratio with Lipofectamine 2000 (Invitrogen) according to the manufacturer's instructions. Plasmid DNA (4 $\mu \mathrm{g}$ ) was mixed with $250 \mu \mathrm{l}$ of serum-free medium (SFM), then $10 \mu 1$ of Lipofectamine 2000 mixed with $250 \mu 1$ of SFM was added, and incubated for $20 \mathrm{~min}$ at room temperature. Finally, the resultant mixture was added to cells in each well. The medium was replaced with fresh serum containing medium $5 \mathrm{~h}$ after transfection. Positive transfected cells were selected with fresh medium containing $500 \mu \mathrm{g} / \mathrm{ml}$ of G418.

Reverse transcription PCR. Total cellular RNA was isolated with TRIzol as described in the manufacturer's instruction (Molecular Research Center, Inc.). For cDNA synthesis, $1 \mu \mathrm{g}$ of total RNA was reverse-transcripted with Moloney murine leukemia virus reverse transcriptase (Fermentas) and oligodT primer under standard conditions. cDNA $(2 \mu 1)$ was PCR-amplified under the following conditions: incubation at $94^{\circ} \mathrm{C}$ for $5 \mathrm{~min}$, followed by 35 cycles denaturing at $94^{\circ} \mathrm{C}$ for $40 \mathrm{sec}$, annealing for $40 \mathrm{sec}$, elongation at $72^{\circ} \mathrm{C}$ for $1 \mathrm{~min}$ and a final extension at $72^{\circ} \mathrm{C}$ for $10 \mathrm{~min}$. Primers for TRAIL are 5'-CCCAAGCTTATGGCTATGATGGAGG TCCA-3' and 5'-CCGCTCGAGTTAGCCAACTAAAA AGGCC-3' $\left(\mathrm{Tm}=60^{\circ} \mathrm{C}\right)$, for GAPDH: 5'-TTGGTATCG TGGAAGGACTCATG-3' and 5'-GTTGCTGTAGCCAA ATTCGTTGT-3' $\left(\mathrm{Tm}=56^{\circ} \mathrm{C}\right)$.

Amplification products were electrophoresed on $1 \%$ agarose gels containing ethidium bromide for visualization under UV light. All PCR reactions were performed at least three times. Densitometric analysis of TRAIL mRNA levels was performed with Gene tools software. GAPDH was used to normalize mRNA levels. Statistical significances were calculated by $\chi^{2}$ test.

Western blotting. Cells were washed once with ice-cold PBS, exposed to $200 \mu 1$ of lysis buffer (Biyuntian, Biotech). After centrifugation at $12,000 \mathrm{rpm}$ for $5 \mathrm{~min}$ at $4^{\circ} \mathrm{C}$, the superrnatants were removed and stored at $-80^{\circ} \mathrm{C}$. Samples $(50 \mu \mathrm{g}$ of whole-cell lysates per lane) were separated by $10 \%$ SDS-PAGE electrophoresis under denaturing conditions and transferred to PVDF membranes (Biyuntian, Biotech). Membranes were blocked with 5\% non-fat milk and probed with rabbit polyclonal antibody against TRAIL (1:333, Santa Cruz Biotechnology, Santa Cruz) or ß-actin (1:333, Beijing Biosynthesis Technology). Goat peroxidase-coupled antirabbit IgG (Promega) was used as secondary antibody. Immunoreactive protein was detected with DAB kit (Amresco Biosciences). Densitometric analysis of TRAIL protein levels was performed with Gene tools software. B-actin was used to normalize protein levels. Statistical significances were calculated by $\chi^{2}$ test.

Clonogenic assays. Clonogenicity was examined by a colony-forming assay. Exponentially growing cells of group 2 and 4 were irradiated at the dose point of $0,1,2,3,4,6$, 8,10 Gy respectively. An appropriate number of cells were seeded into culture flasks in order to obtain similar number of colonies for different doses of irradiation. After 2-3 weeks of incubation, the colonies were fixed and stained by crystal violet. Those colonies containing $>50$ cells were scored as clonogenic survivors. The data were fit into the single-hit multi-target model, and survival curve of both groups were drawn by SPSS 13.0. Radiobiological parameters, such as SF2 (survival fraction at $2 \mathrm{~Gy}$ ), $\mathrm{D}_{0}, \mathrm{D}_{\mathrm{q}}$ and SER (sensitization enhancement ratio) were calculated according to the survival curves. All experiments were performed independently at least three times.

Cell cycle analysis. Control and 6 Gy irradiated cells with or without transfection were harvested by trypsinisation, washed with ice-cold PBS, fixed in $1 \mathrm{ml} 75 \%$ ethanol at $4^{\circ} \mathrm{C}$ for $1-2 \mathrm{~h}$ in the dark. Ethanol was removed by centrifugation (2000 rpm, $4^{\circ} \mathrm{C}$ ), and DNA content was labeled with $1 \mathrm{ml}$ of dye buffer which contains $0.05 \mathrm{mg} / \mathrm{ml}$ propidium iodide (PI) (centrebio) and $0.02 \mathrm{mg} / \mathrm{ml} \mathrm{RNAse} \mathrm{(sigma)} \mathrm{at} 4^{\circ} \mathrm{C}$ in darkness for $20 \mathrm{~min}$. Cells were centrifuged $\left(2000 \mathrm{rpm}, 4^{\circ} \mathrm{C}\right)$ and resuspended in $500 \mu \mathrm{l}$ PBS. Cell cycle analysis was performed by flow cytometry analysis (Beckman Coulter).

Apoptosis quantification. Cells were harvested by trypsinisation, washed with ice-cold PBS and resuspended in $200 \mu 1$ Binding buffer (centrebio), stained with $10 \mu 1$ of $20 \mu \mathrm{g} / \mathrm{ml}$ Annexin-V-FTIC (centrebio) and $10 \mu \mathrm{l}$ of $20 \mu \mathrm{g} / \mathrm{ml}$ PI (centrebio), and incubated in the dark for $15 \mathrm{~min}$ at room temperature, then added $300 \mu \mathrm{l}$ binding buffer. Cell apoptotic profile was analysed immediately in flow cytometry analysis (Beckman Coulter). The percentage of apoptotic cells was obtained from a bivariate histogram of Annexin-V labeled-cells versus propidium iodide labeledDNA. 


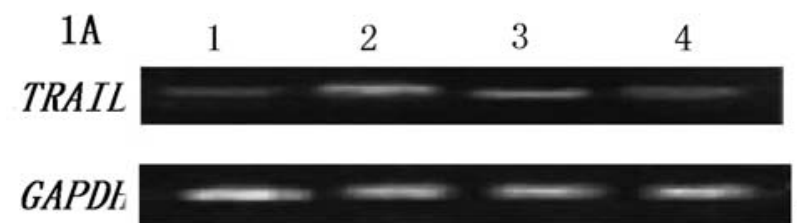

$1 \mathrm{C}$

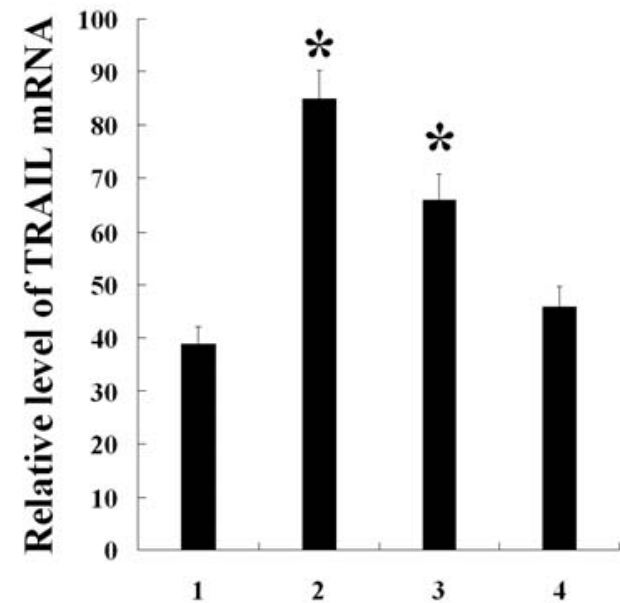

1B TRAIL $\beta$-action

1D

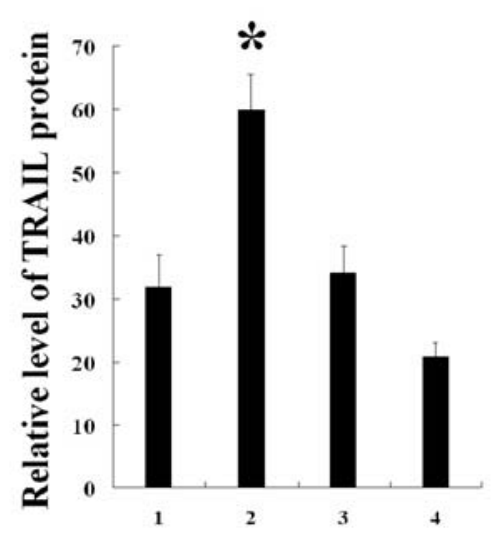

Figure 1. Expression level of TRAIL. (A) Expression level of TRAIL detected by RT-PCR. (B) Expression level of TRAIL detected by Western blotting. 1, Control group; 2, gene radiotherapy group; 3, gene therapy group; 4, radiotherapy group. (C) A graphical representation of the mean data presented in (A). (D) A graphical representation of the mean data presented in (B). The SW480 cell line showed nearly the same expression level of GAPDH mRNA and B-action protein, while displayed evidently increased TRAIL levels in gene radiotherapy group $(\mathrm{P}<0.05)$, as compared with the other three groups. ${ }^{*} \mathrm{P}<0.05$ compared with control (Dunnett test, $\mathrm{n}=3$ ). Columns represent mean data $\pm \mathrm{SD}$.

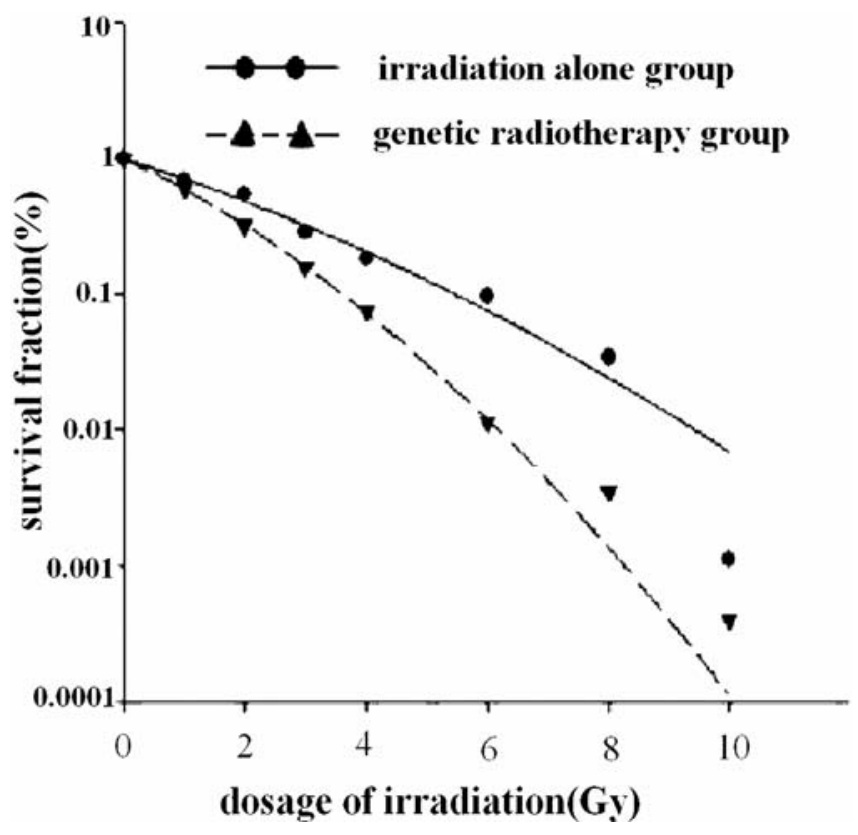

Figure 2. Survival curves. An appropriate number of cells in both groups were seeded into culture flasks for different doses of irradiation. After 2-3 weeks of incubation, the colonies were fixed and stained. Those colonies containing $>50$ cells were scored as clonogenic survivors and the survival fraction was calculated. The data were fit into the single-hit multi-target model, and survival curves of both groups were drawn by software SPSS 13.0. All experiments were performed at least three times. Data were obtained from triplicate samples and expressed as the mean $\pm \mathrm{SD}$.

Statistical analysis. Data were obtained from triplicate samples and expressed as the mean \pm standard deviation (SD). Statistical analysis was performed with software SPSS
13.0, and the comparison of radiobiological parameters was analyzed by Student's t-test. A value of $\mathrm{P}<0.05$ was considered to be statistically significant.

\section{Results}

Expression level of TRAIL. As shown in Fig. 1A and C, cells in pEgr.1-TRAIL transfected groups displayed increased TRAIL mRNA levels compared to control and radiotherapy group $(\mathrm{P}<0.05)$, especially cells in gene radiotherapy group showed the most manifest up-regulation of mRNA level. The result was confirmed by Western blot analysis (Fig. 1B and D). TRAIL up-regulation mediated by Egr-1 promoter could be observed, which proved that Egr-1 promoter is irradiation inducible.

Radiobiological parameters of clonogenic assays. The survival curves describe the radiobiological parameters of both groups (Fig. 2). Compared to the radiotherapy group, the survival fractions of the gene radiotherapy group were much lower at each dose point. The radiobiological parameters calculated are shown in Table I. $\mathrm{D}_{0}$ and SF2 values in gene radiotherapy group are significantly lower than the control group $(\mathrm{P}<0.001)$. The results suggested that pEgr-1-TRAIL plasmid enhanced the radiosensitivity of SW480 cells.

Cell cycle distribution. As shown in Fig. 3, higher fractions of cells in $\mathrm{S}$ phase and lower fractions of cells in G1 phase $(\mathrm{P}<0.01)$ after irradiation were observed in SW480 cells. In addition, expression of TRAIL induced accumulation in the $\mathrm{G} 1(\mathrm{P}<0.05)$ phase and decreased the percentage of cells in the $S$ phase $(\mathrm{P}<0.05)$. 
Table I. Radiobiological parameters.

\begin{tabular}{lccc}
\hline Grouping & $\mathrm{D}_{0}{ }^{\mathrm{a}}$ & $\mathrm{D}_{\mathrm{q}}$ & $\mathrm{SF}^{\mathrm{a}}$ \\
\hline Radiotherapy group & $2.2589 \pm 0.0679$ & $0.1724 \pm 0.0272$ & $0.4701 \pm 0.0114$ \\
Gene radiotherapy group & $1.4575 \pm 0.0235$ & $0.1654 \pm 0.0101$ & $0.3159 \pm 0.0014$ \\
SER & 1.55 & 1.09 & 1.49 \\
\hline
\end{tabular}

Data from triplicate clonogenic assays were fit into the single-hit multi-target model, and survival curves of both groups were drawn by software SPSS 13.0, the SF2, $\mathrm{D}_{0}, \mathrm{D}_{\mathrm{q}}$ and SER values were calculated $\left(\mathrm{P}_{\mathrm{D} 0}, \mathrm{P}_{\mathrm{SF} 2}<0.001\right)$. Data were expressed as the mean $\pm \mathrm{SD}$. ${ }^{\text {andicates }}$ statistic significances $(\mathrm{P}<0.001)$. SF, surviving fraction; $\mathrm{D}_{0}$, mean lethal dose, is also known as final slope; $\mathrm{D}_{\mathrm{q}}$, quasi-threshold dose.

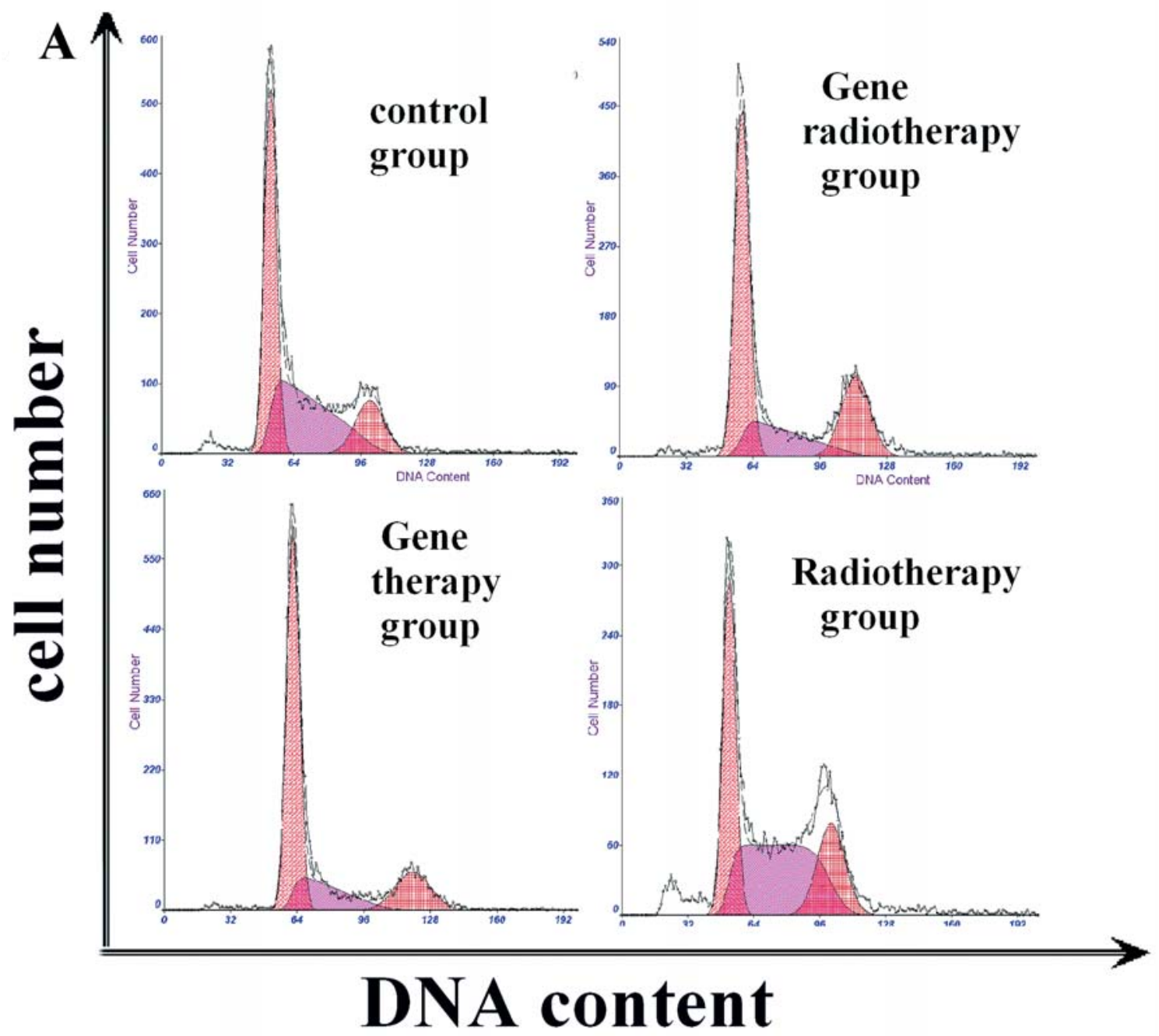

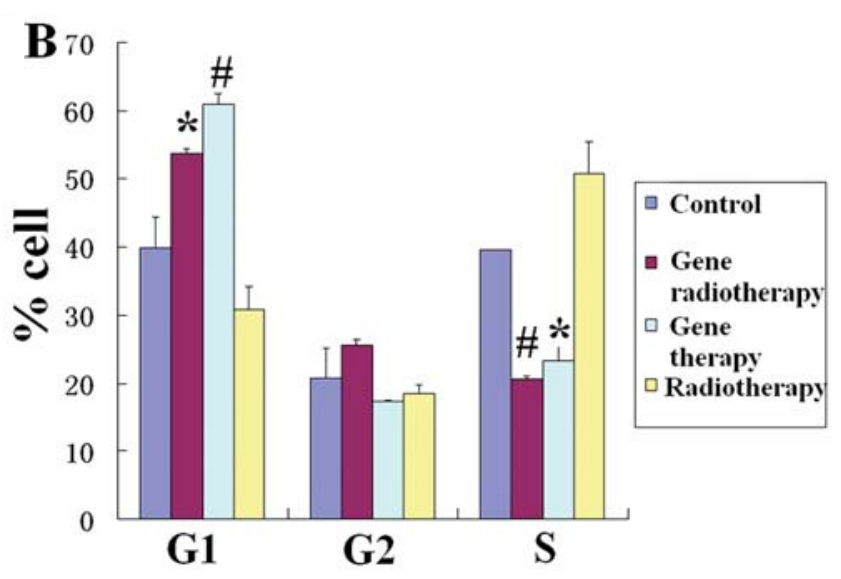

Figure 3. Cell cycle distribution. (A) Four groups of cells were incubated for $24 \mathrm{~h}$ after irradiation or sham irradiation were analyzed by flow cytometry respectively; (B) Cell cycle changes evaluated between groups in histogram. Cells treated with transfection displayed accumulation in the $\mathrm{G} 1$ phase and decreased percentage of cells in the $\mathrm{S}$ phase. At the same time, it shows higher fractions of cells in $\mathrm{S}$ and lower fractions of cells in G1 phase after irradiation. ${ }^{*} \mathrm{P}<0.05,{ }^{\#} \mathrm{P}<0.01$ compared with control (Dunnett test, $\mathrm{n}=3$ ). Columns represent mean data $\pm \mathrm{SD}$.

Apoptosis quantification. Induction of apoptosis was associated with cycle changes at the 24-h incubation time after radiation. As shown in Fig. 4, our data show significant differences in the apoptotic rates between each group (Fig. 4). 


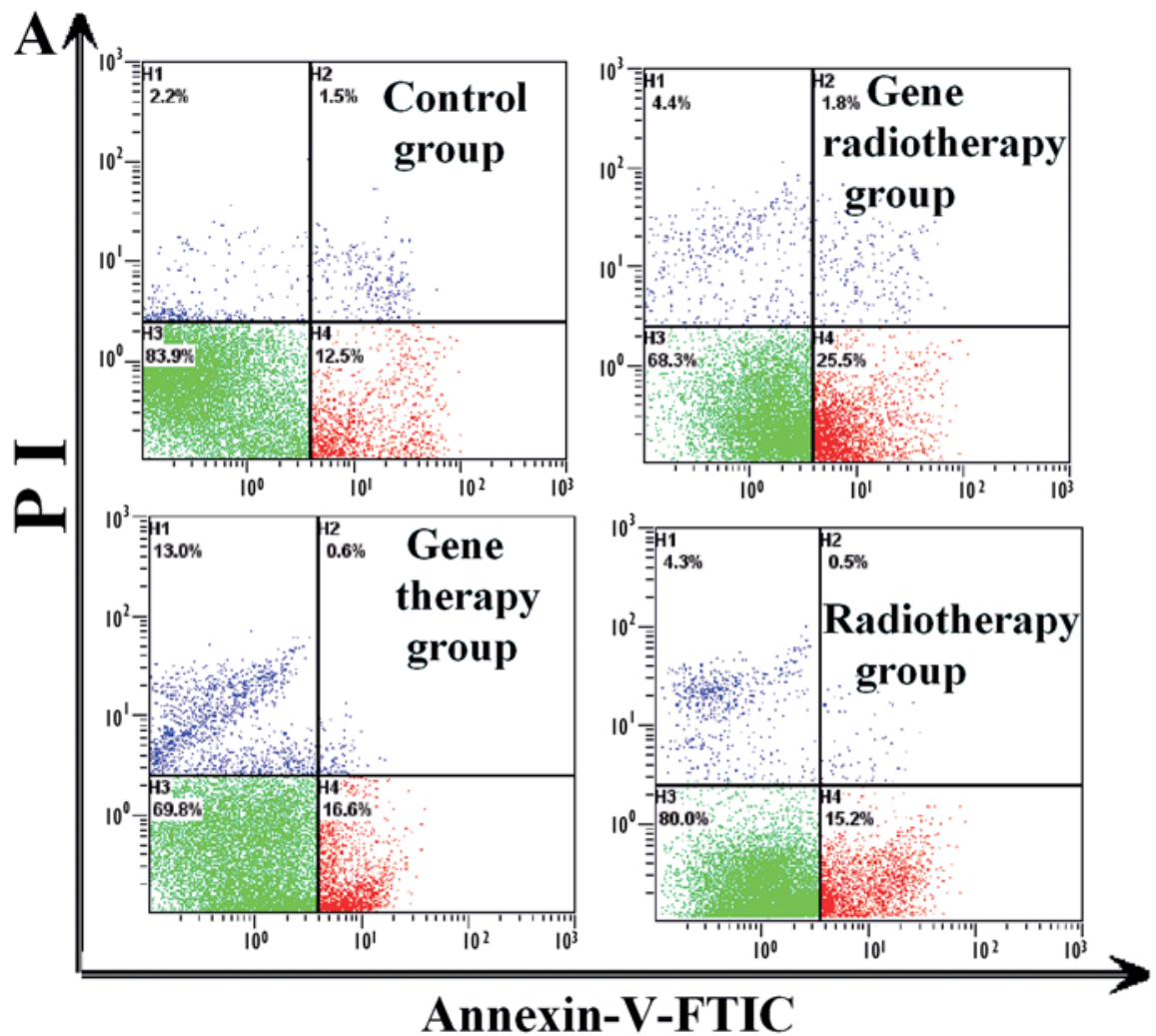

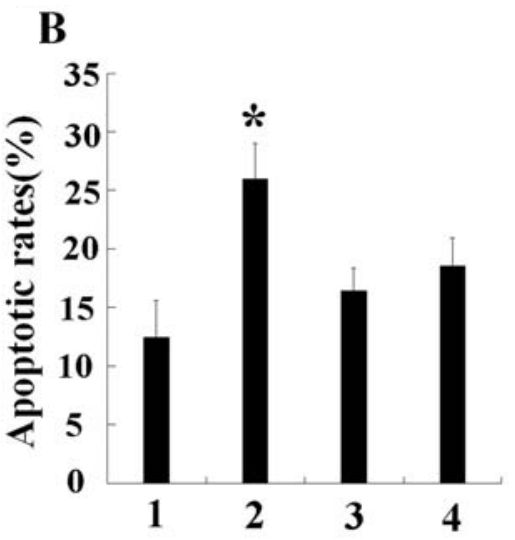

In particularly, gene radiotherapy group demonstrated the highest apoptotic rate $(\mathrm{P}<0.05)$, suggesting that increasing apoptosis is involved in the mechanism of radiosensitisation induced by TRAIL.

\section{Discussion}

In the present study, we showed that TRAIL expression mediated by Egr-1 promoter sensitized SW480 to radiotherapy via apoptosis pathway. For the radiotherapy (6 Gy) only group, the killing effect on tumor cells was minimal, mean apoptosis ratio is $18.0 \%$ (Fig. 4). There is no statistical difference compared with control group. These data suggest that SW480 cell line is resistant to radiotherapy at this dose. Similarly, transfection of pEgr.1-TRAIL alone moderately diminished the tumor resistance phenotype. However, combination of radiotherapy and pEgr.1-TRAIL displayed a synergetic effect on the apoptotic rate (Fig. 4) and clone formation assay (Fig. 2). The combined treatment may serve
Figure 4. Apoptosis quantification. (A) Apoptotic cells were detected by FTIC-conjugated Annexin-V and propidium iodide (PI) double labeling method. Four groups of cells incubated $24 \mathrm{~h}$ after irradiation or sham irradiation were analyzed by flow cytometry respectively. The left lower quadrant indicates normal cells; the left upper quadrant indicates dead cells due to mechanical damage; the right lower quadrant indicates cells of apoptosis; the right upper quadrant indicates cells of necrosis or apoptosis. (B) A graphical representation of the mean data presented in (A). 1, Control group; 2, Gene radiotherapy group; 3 , Gene therapy group; 4 , Radiotherapy group. ${ }^{*} \mathrm{P}<0.05,{ }^{*} \mathrm{P}<0.01$ compared with control (Dunnett test, $\mathrm{n}=3$ ). Columns represent mean data \pm SD. Cells treated with transfection and irradiation displayed a significant increased percentage of apoptotic cells.

as a novel approach to improve the therapeutic ratio of radiotherapy in colon cancer.

Radiotherapy commonly causes acute and chronic adverse effects, which are the major dose-limiting toxicities of radiotherapy (14), especially in colon cancer with critical surrounding organs. While gene therapy causes different toxicity profiles, such as fevers (15). Therefore, combined gene therapy and radiotherapy may increase therapeutic efficacy on cancer cells, with tolerable toxicities. Among the family of death receptor ligands, tumor necrosis factor and Fas have been extensively investigated, a phase I clinical trial has been completed with TNF- $\alpha$ (16). TRAIL is an attractive candidate for cancer treatment due to its ability to induce apoptosis selectively in cancer cells (11), which is related to differential distribution of TRAIL-receptors. TRAIL interacts with four homologous TRAIL receptors. Both DR4 and DR5 expressed mainly on tumor cells transducing apoptotic signals when binding with TRAIL, while DcR1 and DcR2 expressed mainly on normal cells functioning as decoys or transduce anti-apoptotic signals (17). DR4 and DR5 expressed at high levels in the majority of colon carcinomas (18). Therefore, TRAIL is a more potent approach with more specificity and safety in treatment of colon carcinoma. More- 
over, TRAIL gene therapy may overcome problems observed with the use of soluble recombinant TRAIL regarding protein instability and resistance $(19,20)$, and untransfected neighboring cancer cells can be killed by a TRAIL-mediated bystander effect $(21,22)$. The only reported toxicity to normal cells is the induction of apoptosis in human primary hepatocytes (23) and brain cells (24) in vitro. To minimize such toxicities, we developed a radioresponsive gene expression system by controlling TRAIL expression mediated by Egr.1 promoter following irradiation. The six $\mathrm{CArG}(\mathrm{CC}(\mathrm{A} / \mathrm{T})$ 6GG) elements in the upstream sequence of Egr.1 promoter can mediate transcription of downstream gene (25). In our previous study (26), the induction response to irradiation peaked at $6 \mathrm{~Gy}$, then decreased in a dose-dependent manner. Consistently, the activation of Egr-1 promoter was the highest after $24 \mathrm{~h}$ with 6 Gy irradiation, then decreased in a timedependent manner. As in this study, the expression of TRAIL $24 \mathrm{~h}$ after 6 Gy irradiation was significantly higher (Fig. 1, $\mathrm{P}<0.05$ ), and TRAIL under the control of radioresponsive promoter induced apoptosis and sensitized radiotherapy in SW480 cell line.

An enhanced anticancer effect of the combination of TRAIL gene therapy with radiotherapy has been reported in various cancer cells, including breast cancer (27), neurogliocytoma (28), leukemia, and lymphoma (29) cells. Our results also showed a similar effect on colon cancer cells. We thought such effects could be explained by the following mechanisms. First, TRAIL and radiation activate distinct apoptotic pathways but result in an amplified response (30). TRAIL binds with DR4/DR5 and activates caspase-8, subsequently activates caspase- 3 , resulting in activation of a cascade of caspases (31). In addition, caspase- 8 can also activate $\mathrm{Bid}$ that triggers cytochrome c release, with subsequent activation of caspase- 9 and caspase-3, thereby strongly amplifying the initial apoptotic signal (32). However, radiation activates the p53-dependent apoptosis pathway by direct DNA damage (33), loss of mitochondrial membrane potential and cyto-chrome c releasing $(34,35)$, which led to caspase-9 activation (36). Alternatively, radiation may directly damage the cellular membrane resulting in the release of ceramide (37), which can directly damage mitochondrial membrane and then stimulate apoptosis by releasing cytochrome c. Therefore, distinct apoptotic pathways induced by combination of TRAIL with radiotherapy will exert synergistic effects on trans-formed cells. Second, It is reported that DR5 overexpression in TRAIL resistant cancer cells could restore TRAIL sensitivity $(38,39)$. Other studies and our previous study confirmed ionizing radiation could up-regulate expression of DR5 $(12,13)$, which indicates radiotherapy may overcome the TRAIL resistance in malignant cells. Moreover, ionizing radiation can improve transfection efficiency (40). Finally, TRAIL gene therapy and radiotherapy target different phases of the cell cycle. The G1 or S phases being most responsive to TRAIL $(41,42)$ and the $G 1$ and $G 2$ phases being most radiosensitive $(43,44)$. Our data showed a higher proportion in $\mathrm{S}$ phase after irradiation and a higher proportion in G1 phase with transfection of pEgr.1-TRAIL (Fig. 3), which demonstrated a synergistic and additive effect on inducing apoptosis.
In summary, our data showed that tumor-specific TRAIL gene mediated by radioresponsive Egr.1 promoter sensitized SW480 cells to radiotherapy. pEgr.1-TRAIL may increase the therapeutic efficacy of ionizing radiation or reduce radiation-mediated side effects, and radiotherapy may also overcome the TRAIL resistance in highly malignant cancer cells. It indicates that radioresponsive gene therapy may have great potential as a novel therapy because this therapeutic approach can be spatially or temporally controlled by radiotherapy and appears to have better specificity and safety.

\section{Acknowledgements}

We are very grateful to Dr Wu Cong-Mei and Dr J.Y. Chang for kindly providing the plasmids pMD18T-Egr-1 and PAAV-TRAIL, and to Dr Wang Fangkui and Dr Wang Li for excellent technical support, and to Mrs. Virginia Robey for wonderful editorial work of this manuscript. This study was supported by Hubei Provincial Keji Gongguan Program (NO 2005AA304B04).

\section{References}

1. Hingorani M, White CL, Agrawal VK, Vidal L, Melcher A and Harrington KJ: Combining radiation and cancer gene therapy: a potential marriage of physical and biological targeting? Curr Cancer Drug Targets 7: 389-409, 2007.

2. McBride WH, Chiang CS, Olson JL, Wang CC, Hong JH, Pajonk F, Dougherty GJ, Iwamoto KS, Pervan M and Liao YP: A sense of danger from radiation. Radiat Res 162: 1-19, 2004.

3. Borgmann K, Roper B, El-Awady R, Brackrock S, Bigalke M, Dork T, Alberti W, Dikomey E and Dahm-Daphi J: Indicators of late normal tissue response after radiotherapy for head and neck cancer: fibroblasts, lymphocytes, genetics, DNA repair, and chromosome aberrations. Radiother Oncol 64: 141-152, 2002.

4. Vogelstein B, Fearon ER, Hamilton SR, Kern SE, Preisinger AC, Leppert M, Nakamura Y, White R, Smits AM and Bos JL: Genetic alterations during colorectal-tumor development. N Engl J Med 319: 525-532, 1988.

5. Stevens CW, Zeng $M$ and Cerniglia GJ: Ionizing radiation greatly improves gene transfer efficiency in mammalian cells. Hum Gene Ther 7: 1727-1734, 1996.

6. Zeng M, Cerniglia GJ, Eck SL and Stevens CW: High-efficiency stable gene transfer of adenovirus into mammalian cells using ionizing radiation. Hum Gene Ther 8: 1025-1032, 1997.

7. Hsu H, Rainov NG, Quinones A, Eling DJ, Sakamoto KM and Spear MA: Combined radiation and cytochrome CYP4B1/4ipomeanol gene therapy using the EGR 1 promoter. Anticancer Res 23: 2723-2728, 2003.

8. Zwiebel JA: Cancer gene and oncolytic virus therapy. Semin Oncol 28: 336-3343, 2001.

9. Wiley SR, Schooley K, Smolak PJ, et al: Identification and characterization of a new member of the TNF family that induces apoptosis. Immunity 3: 673-682, 1995.

10. LeBlanc HN and Ashkenazi A: Apo2L/TRAIL and its death and decoy receptors. Cell Death Differ 10: 66-75, 2003.

11. Smyth MJ, Takeda K, Hayakawa Y, Peschon JJ, van den Brink MR and Yagita H: Nature's TRAIL - on a path to cancer immunotherapy. Immunity 18: 1-6, 2003.

12. Tsurushima H, Yuan X, Dillehay LE and Leong KW: Radioresponsive tumor necrosis factor-related apoptosis-inducing ligand (TRAIL) gene therapy for malignant brain tumors. Cancer Gene Ther 14: 706-716, 2007.

13. Wu F, Hu Y, Long J, Zhou YJ, Zhong YH, Liao ZK, Liu SQ, Zhou FX, Zhou YF and Xie CH: Cytotoxicity and radiosensitization effect of TRA-8 on radioresistant human larynx squamous carcinoma cells. Oncol Rep 21: 461-465, 2009.

14. Zhu H, Cao CH and Xie CH: The Property of Egr-1 promoter in irradiation-induced gene expression. Med J Wuhan Univ 29: 186-189, 2008.

15. Mathes SJ and Alexander J: Radiation injury. Surg Oncol Clin N Am 5: 809-824, 1996. 
16. Swisher SG, Roth JA, Komaki R, Gu J, Lee JJ, Hicks M, Ro JY, Hong WK, Merritt JA, Ahrar K, Atkinson NE, Correa AM, Dolormente M, Dreiling L, El-Naggar AK, Fossella F, Francisco R, Glisson B, Grammer S, Herbst R, Huaringa A, Kemp B, Khuri FR, Kurie JM, Liao Z, McDonnell TJ, Morice R, Morello F, Munden R, Papadimitrakopoulou V, Pisters KM, Putnam JB Jr, Sarabia AJ, Shelton T, Stevens C, Shin DM, Smythe WR, Vaporciyan AA, Walsh GL and Yin M: Induction of p53-regulated genes and tumor regression in lung cancer patients after intratumoral delivery of adenoviral p53 (INGN 201) and radiation therapy. Clin Cancer Res 9: 93-101, 2003.

17. Senzer N, Mani S, Rosemurgy A, Nemunaitis J, Cunningham C, Guha C, Bayol N, Gillen M, Chu K, Rasmussen C, Rasmussen H, Kufe D, Weichselbaum R and Hanna N: TNFerade biologic, an adenovector with a radiation-inducible promoter, carrying the human tumor necrosis factor alpha gene: a phase I study in patients with solid tumors. J Clin Oncol 22: 592-601, 2004.

18. Ashkenazi A and Dixit VM: Apoptosis control by death and decoy receptors. Curr Opin Cell Biol 11: 255-260, 1999.

19. Strater J, Hinz U, Walczak H, Mechtersheimer G, Koretz K Herfarth C, Moller P and Lehnert T: Expression of TRAIL and TRAIL receptors in colon carcinoma: TRAIL-R1 is an independent prognostic parameter. Clin Cancer Res 8: 3734-3740, 2002.

20. Voelkel-Johnson C, King DL and Norris JS: Resistance of prostate cancer cells to soluble TNF-related apoptosis-inducing ligand (TRAIL/Apo2L) can be overcome by doxorubicin or adenoviral delivery of full-length TRAIL. Cancer Gene Ther 9: 164-172, 2002.

21. Seol JY, Park KH, Hwang CI, Park WY, Yoo CG, Kim YW, Han SK, Shim YS and Lee CT: Adenovirus-TRAIL can overcome TRAIL resistance and induce a bystander effect. Cancer Gene Ther 10: 540-548, 2003.

22. Kagawa S, He C, Gu J, Koch P, Rha SJ, Roth JA, Curley SA, Stephens LC and Fang B: Antitumor activity and bystander effects of the tumor necrosis factor-related apoptosis-inducing ligand (TRAIL) gene. Cancer Res 61: 3330-3338, 2001.

23. Huang X, Lin T, Gu J, Zhang L, Roth JA, Liu J and Fang B: Cell to cell contact required for bystander effect of the TNFrelated apoptosis-inducing ligand (TRAIL) gene. Int J Oncol 22: 1241-1245, 2003.

24. Jo M, Kim TH, Seol DW, Esplen JE, Dorko K, Billiar TR and Strom SC: Apoptosis induced in normal human hepatocytes by tumor necrosis factor-related apoptosis-inducing ligand. Nat Med 6: 564-567, 2000

25. Nitsch R, Bechmann I, Deisz RA, Haas D, Lehmann TN, Wendling $U$ and Zipp F: Human brain-cell death induced by tumour-necrosis-factor-related apoptosis-inducing ligand (TRAIL). Lancet 356: 827-828, 2000.

26. Datta R, Rubin E, Sukhatme V, Qureshi S, Hallahan D, Weichselbaum RR and Kufe DW: Ionizing radiation activates transcription of the EGR1 gene via CArG elements. Proc Natl Acad Sci USA 89: 10149-10153, 1992.

27. Chinnaiyan AM, Prasad U, Shankar S, Hamstra DA, Shanaiah M, Chenevert TL, Ross BD and Rehemtulla A: Combined effect of tumor necrosis factor-related apoptosis-inducing ligand and ionizing radiation in breast cancer therapy. Proc Natl Acad Sci USA 97: 1754-1759, 2000.

28. Dai DJ, Xie CH, Zhang AL, Qiu HB and Zhou ZY: Experimental study on synergistic effect of TRAIL combined with radioactive ray on human U251 glioma cell lines. Med J Wuhan Univ 27: 759-762, 2006.
29. Gong B and Almasan A: Apo2 ligand/TNF-related apoptosisinducing ligand and death receptor 5 mediate the apoptotic signaling induced by ionizing radiation in leukemic cells. Cancer Res 60: 5754-5760, 2000.

30. Belka C, Jendrossek V, Pruschy M, Vink S, Verheij M and Budach W: Apoptosis-modulating agents in combination with radiotherapy-current status and outlook. Int J Radiat Oncol Biol Phys 58: 542-554, 2004.

31. Stennicke HR, Jurgensmeier JM, Shin H, Deveraux Q, Wolf BB Yang X, Zhou Q, Ellerby HM, Ellerby LM, Bredesen D, Green DR, Reed JC, Froelich CJ and Salvesen GS: Pro-caspase-3 is a major physiologic target of caspase-8. J Biol Chem 273: 27084-27090, 1998.

32. Luo X, Budihardjo I, Zou H, Slaughter C and Wang X: Bid, a Bcl2 interacting protein, mediates cytochrome $\mathrm{c}$ release from mitochondria in response to activation of cell surface death receptors. Cell 94: 481-490, 1998.

33. Ferreira CG, Epping M, Kruyt FA and Giaccone G: Apoptosis: target of cancer therapy. Clin Cancer Res 8: 2024-2034, 2002.

34. Nakano K and Vousden KH: PUMA, a novel proapoptotic gene, is induced by p53. Mol Cell 7: 683-694, 2001.

35. Wei MC, Zong WX, Cheng EH, Lindsten T, Panoutsakopoulou V, Ross AJ, Roth KA, MacGregor GR, Thompson CB and Korsmeyer SJ: Proapoptotic BAX and BAK: a requisite gateway to mitochondrial dysfunction and death. Science 292: 727-730, 2001

36. Li P, Nijhawan D, Budihardjo I, Srinivasula SM, Ahmad M, Alnemri ES and Wang X: Cytochrome $\mathrm{c}$ and dATP-dependent formation of Apaf-1/caspase-9 complex initiates an apoptotic protease cascade. Cell 91: 479-489, 1997.

37. Haimovitz-Friedman A, Kan CC, Ehleiter D, Persaud RS, McLoughlin M, Fuks Z and Kolesnick RN: Ionizing radiation acts on cellular membranes to generate ceramide and initiate apoptosis. J Exp Med 180: 525-535, 1994.

38. Mitsiades N, Poulaki V, Mitsiades C and Tsokos M: Ewing's sarcoma family tumors are sensitive to tumor necrosis factorrelated apoptosis-inducing ligand and express death receptor 4 and death receptor 5. Cancer Res 61: 2704-2712, 2001

39. Kuang AA, Diehl GE, Zhang J and Winoto A: FADD is required for DR4- and DR5-mediated apoptosis: lack of trail-induced apoptosis in FADD-deficient mouse embryonic fibroblasts. J Biol Chem 275: 25065-25068, 2000.

40. Srivastava RK, Chen Q, Siddiqui I, Sarva K and Shankar S: Linkage of curcumin-induced cell cycle arrest and apoptosis by cyclin-dependent kinase inhibitor p21(/WAF1/CIP1). Cell Cycle 6: 2953-2961, 2007.

41. Shi MD, Lin HH, Lee YC, Chao JK, Lin RA and Chen JH: Inhibition of cell-cycle progression in human colorectal carcinoma Lovo cells by andrographolide. Chem Biol Interact 174: 201-210, 2008.

42. Teyssier F, Bay JO, Dionet C and Verrelle P: Cell cycle regulation after exposure to ionizing radiation. Bull Cancer 86: 345-357, 1999.

43. Hunakova L, Chorvath M, Duraj J, Bartosova Z, Sevcikova L, Sulikova M, Chovancova J, Sedlak J, Chorvath B and Boljesikova E: Radiation-induced apoptosis and cell cycle alterations in human carcinoma cell lines with different radiosensitivities. Neoplasma 47: 25-31, 2000 . 